\title{
Indomethacin and Platelet Aggregation in Chronic Glomerulonephritis: Existence of Non-responders
}

\author{
G. DE GAETANO, J. VERMYLEN, \\ M. B. DONATI, \\ G. DOTREMONT, \\ P. MICHIELSEN
}

British Medical fournal, 1974, 2, 301-303

\begin{abstract}
Summary
Indomethacin given to adults with glomerulonephritis usually reduces their urinary excretion of protein and fibrinogen/ fibrin-related (F.R.) antigen. Nevertheless, non-responders exist. Platelet aggregation is significantly more strongly inhibited by indomethacin in good responders than in nonresponders. This supports the hypothesis that the reduction of urinary excretion of F.R. antigen during indomethacin administration is related, at least in part, to inhibition of intrarenal platelet aggregation and of the subsequent fibrin deposition.
\end{abstract}

\section{Introduction}

Indomethacin can greatly reduce proteinuria in patients with chronic glomerulonephritis (Michielsen and Verberckmoes, 1967; Michielsen et al., 1969, 1970). Urinary fibrinogen/fibrinrelated (F.R.) antigen may also be reduced significantly after the administration of indomethacin to such patients (Vermylen et al., 1970, 1971), but some subjects are nonresponders (Clarkson et al., 1972). Intrarenal fibrin deposition often occurs in glomerulonephritis (Vassalli and McCluskey, 1965), and it has been suggested that the reduced urinary excretion of F.R. antigen after the administration of indomethacin results from decreased glomerular fibrin formation (Vermylen et al., 1970; Clarkson et al., 1972), possibly due to the inhibition of platelet aggregation by this drug (Vermylen et al., 1970). A single dose of indomethacin (0.035-1.2 mg/ $\mathrm{kg}$ ) given to normal subjects inhibits platelet aggregation for six to eight hours (O'Brien et al., 1970; Vermylen et al., 1970); this effect lasts slightly longer with repeated ingestion over 48 hours (O'Brien et al., 1970). The bleeding time is pnolonged

Academisch Ziekenhuis St. Rafaël, University of Leuven, Belgium G. DE GAETANO, M.D., Research Fellow, Laboratory of Blood Coagulation (Present address: Laboratory for Haemostasis and Thrombosis Research, Mario Negri Institute, V. Eritrea, 62-20157 Milan, Italy)

J. VERMYLEN, M.D., Lecturer in Medicine, Medical Research Department and Department of Medicine

M. B. DONATI, M.D., Research Fellow, Laboratory of Blood Coagulation (Present address: Laboratory for Haemostasis and Thrombosis Research, Mario Negri Institute, V. Eritrea, 62-20157 Milan, Italy)

G. DOTREMONT, M.D., Resident, Section of Nephrology

P. MICHIELSEN, M.D., Professor of Medicine, Section of Nephrology but coagulation and fibrinolysis are not changed (de Gaetano et al., 1971).

The present study aimed at defining the effect of long-term indomethacin administration on platelet aggregation in patients with chronic glomerulonephritis. In particular, we wanted to see whether platelet aggregation would be less inhibited in non-responders-that is, patients whose urinary excretion of F.R. antigen is not reduced by indomethacin.

\section{Patients and Methods}

Altogether 35 patients (24 men and 11 women aged 16-54 years) with histologically definite glomerulonephritis were examined. All had been taking indomethacin (75-175 $\mathrm{mg} /$ day) for 5 to 36 months. Blood was collected 3 to 12 hours after the last dose of indomethacin in 9 cases (group 1), 13 to 24 hours afterwards in 16 cases (group 2), and more than 24 hours afterwards in 10 cases (group 3). These three groups of patients showed no significant difference in age, proteinuria, excretion of fibrinogen-like material, creatinine clearance, or histological lesions.

Of the patients in group 2, 14 (8 men and 6 women aged 16-40 years) were funther examined 60 minutes after a single 50 -mg dose of indomethacin by mouth. Ten normal subjects (five men and five women) were also examined before and at different intervals after a test dose of $50 \mathrm{mg}$ of indomethacin.

The 24-hour urinary excretion of F.R. antigen was determined as described (Vermylen et al., 1970). Platelets were counted by phase micnoscopy using the Unopette (BectonDickinson). Platelet aggregation was studied at $37^{\circ} \mathrm{C}$ in a Born aggregometer using $0.8 \mathrm{ml}$ of platelet-rich plasma (adjusted to about 300,000 platelets $/ \mathrm{mm}^{3}$ by dilution with plateletpoor plasma from the same subject) and $0.2 \mathrm{ml}$ of the following aggregation inducers: sodium salt of adenosine-5diphosphate (Sigma) $2 \cdot 10^{-5} \mathrm{~mol} / 1$; adrenaline (Stago) $50 \mu \mathrm{g} /$ $\mathrm{ml}$; undiluted Thrombofax; and a purified bovine fibrinogen preparation (Kabi) $200 \mathrm{mg} / 100 \mathrm{ml}$. All these reagents were dissolved or diluted in Michaelis buffer at pH 7.3 (Stago). The modifications of light transmission were monitored for at least 10 minutes by a recorder (Vitatron) connected to the aggregometer. The response to the platelet aggregation tests was defined as either normal or abnormal using the criteria in table I.

\section{Results}

The inhibitory effect of indomethacin on platelet aggregation was found to be maximal in the first 12 hours after ingestion,

TABLE I-Criteria for Evaluation of Response to Platelet Aggregation Tests

\begin{tabular}{|c|c|c|c|c|}
\hline \multirow{2}{*}{\multicolumn{3}{|c|}{ Aggregation Inducer }} & \multicolumn{2}{|c|}{ Response } \\
\hline & & & Normal & Abnormal (Inhibition) \\
\hline 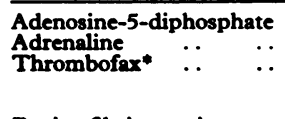 & $\begin{array}{l}. \\
\because\end{array}$ & $\begin{array}{l}\cdots \\
\because \\
\cdots\end{array}$ & $\begin{array}{l}\text { Irreversible aggregation } \\
\text { Two waves } \\
\text { Latent period shorter than } 2 \text { min; maximal slope 20.6-52.6 } \\
\text { TU/min; maximal amplitude 30.7-59.1 TU }\end{array}$ & $\begin{array}{l}\text { Disaggregation within } 10 \text { min. } \\
\text { Absence of second wave } \\
\text { Latent period longer than } 2 \text { min. and/or maximal slope less } \\
\text { than } 20.6 \mathrm{TU} / \mathrm{min} \text { and/or maximal amplitude less than } \\
30.7 \mathrm{TU} \text {. }\end{array}$ \\
\hline Bovine fibrinogen $\dagger$ & .. & .. & Unique, irreversible wave or two waves & Disaggregation within $10 \mathrm{~min}$ or absence of second wave \\
\hline
\end{tabular}

- See de Gaetano et al. (1972). IIt has recently been shown (Forbes and Prentice, 1972, 1973; Donati et al., 1973) that bovine factor VIII present in bovine fibrinogen is responsible for platelet aggregation.
TU = Transmission units. 
still detectable in some patients after 13 to 24 hours, and almost completely absent after 24 hours (table II). The effect produced by the $50-\mathrm{mg}$ test dose was statistically significant in both groups of subjects (table III) though it was more striking in the controls, notwithstanding the effect of previous drug administration in the glomerulonephritis group.

Patients in whom indomethacin treatment had reduced the mean urinary excretion of F.R. antigen by over half gave significantly more abnormal responses to the platelet tests before the test dose than did patients in whom the urinary excretion of F.R. antigen had been less noticeably reduced (table IV). The explanation that the latter patients may not have taken indomethacin the day before the test is invalidated by the fact that even after the test dose these patients gave significantly fewer abnormal responses. Similar results were obtained when the patients were divided into two groups on the basis of degree of reduction of proteinuria during previous indomethacin administration (table IV); patients with a large reduction gave significantly more abnormal responses to the platelet aggregation tests both before and after the test dose than did patients with no or a slight reduction.

Platelet response was also related to the mean levels of proteinuria (table V) and creatinine clearance (table VI) during the treatment with indomethacin (mean follow-up 7.9 months). Patients with a mean proteinuria below $6 \mathrm{~g} / 24 \mathrm{hr}$ showed a statistically significant number of modifications of their responses to the platelet aggregation tests after the test dose, whereas patients with a proteinuria of over $6 \mathrm{~g} / 24 \mathrm{hr}$ did

TABLE II-Effect of Indomethacin on Distribution of Normal and Abnormal Responses to Platelet Aggregation Tests in Glomerulonephritis Patients

\begin{tabular}{|c|c|c|c|c|c|c|c|c|}
\hline \multirow[b]{2}{*}{ Group } & \multirow[b]{2}{*}{$\begin{array}{l}\text { Time Since Last Dose } \\
\text { of Indomethacin }\end{array}$} & \multirow[b]{2}{*}{$\begin{array}{l}\text { No. of } \\
\text { Subiects }\end{array}$} & \multirow[b]{2}{*}{$\begin{array}{l}\text { No. of } \\
\text { Tests }\end{array}$} & \multicolumn{3}{|c|}{ No. of Subjects with: } & \multicolumn{2}{|c|}{ Overall No. of Tests producing: } \\
\hline & & & & $\begin{array}{c}\text { Completely } \\
\text { Normal } \\
\text { Response }\end{array}$ & $\begin{array}{c}1 \text { or } 2 \\
\text { Abnormal } \\
\text { Responses } \\
\end{array}$ & $\begin{array}{c}3 \text { or } 4 \\
\text { Abnormal } \\
\text { Responses }\end{array}$ & $\begin{array}{c}\text { Normal } \\
\text { Response }\end{array}$ & $\begin{array}{l}\text { Abnormal } \\
\text { Response }\end{array}$ \\
\hline $\begin{array}{l}1 \\
2 \\
3 \\
\end{array}$ & $\begin{array}{l}\text { 3-12 Hours } \\
\text { 13-24 Hours } \\
\text { More than 24 Hours }\end{array}$ & $\begin{array}{r}9 \\
16 \\
10 \\
\end{array}$ & $\begin{array}{l}36 \\
64 \\
34 \\
\end{array}$ & $\begin{array}{l}3 \\
7 \\
8 \\
\end{array}$ & $\begin{array}{l}1 \\
6 \\
2 \\
\end{array}$ & $\begin{array}{l}5 \\
3 \\
0 \\
\end{array}$ & $\begin{array}{l}18 \\
43 \\
32 \\
\end{array}$ & $\begin{array}{r}18 \\
21 \\
2\end{array}$ \\
\hline Controls & & 10 & 35 & 9 & 1 & 0 & 34 & 1 \\
\hline
\end{tabular}

Statistical evaluation of overall results (last column) was as follows-Group 1 v. group $2: x^{2}=2 \cdot 2$, N.S.; group 1 v. group $3: \chi^{2}=14 \cdot 6, P<0 \cdot 001$; group 2 v. group 3: $\chi^{2}=$ 7.5, P <0.01; group $1 v$. controls: $x^{3}=17.79$, P 0.001 ; group 2 v. controls: $x^{3}=10.08,0.01>P>0.001$. TABLE III-Effect on Platelet Aggregation of 50-mg Test Dose of Indomethacin by Mouth in 10 Normal Subjects and in 14 Glomerulonephritis Patients
already on this Drug

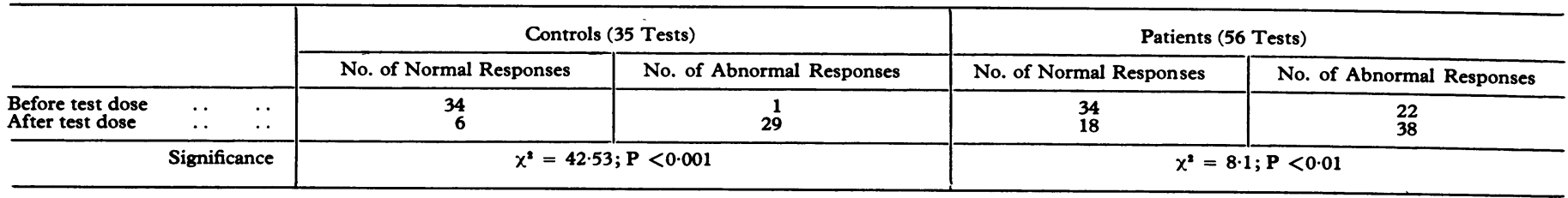

TABLE IV-Responses of Urinary F.R. Antigen Excretion and Proteinuria to Prolonged Indomethacin Administration and Platelet Response to Test Dose

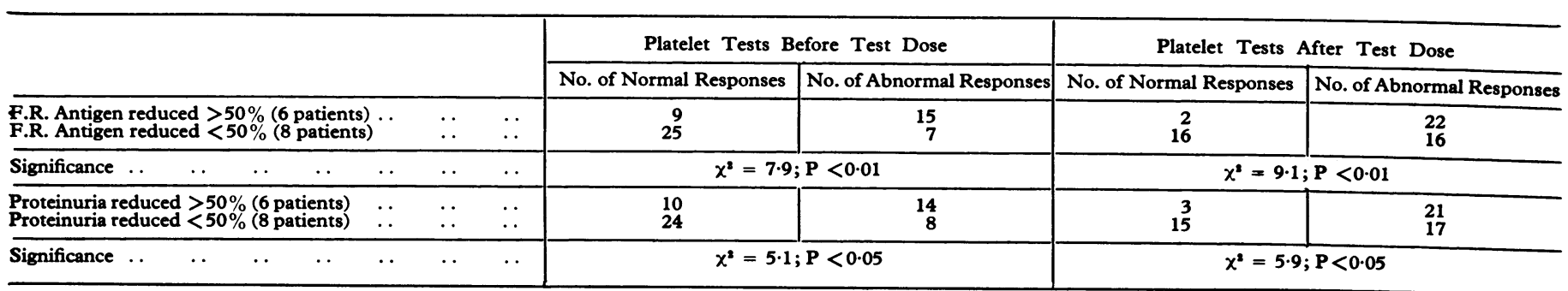

TABLE V-Relation between Proteinuria and Platelet Response to Test Dose of Indomethacin in Glomerulonephritis Patients

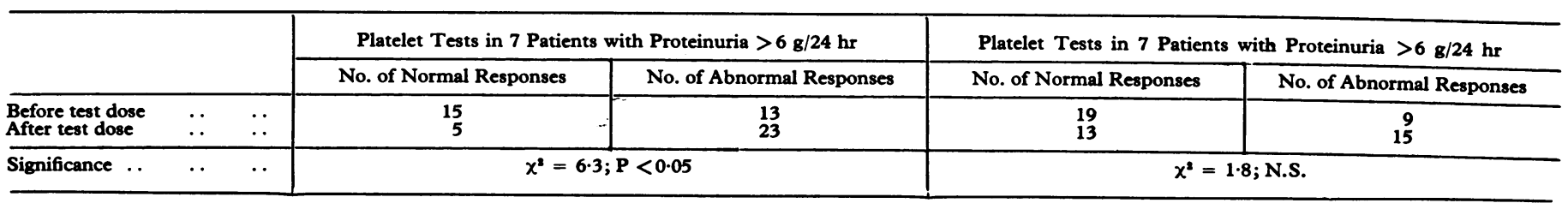

TABLE VI-Relation between Creatinine Clearance and Platelet Response to Test Dose of Indomethacin in Glomerulonephritis Patients

\begin{tabular}{|c|c|c|c|c|c|}
\hline & & \multicolumn{2}{|c|}{ Platelet Tests in 8 Patients with Creatinine Clearance $>60 \mathrm{ml} / \mathrm{min}$} & \multicolumn{2}{|c|}{ Platelet Tests in 6 Patients with Creatinine Clearance $<60 \mathrm{ml} / \mathrm{min}$} \\
\hline & & No. of Normal Responses & No. of Abnormal Responses & No. of Normal Responses & No. of Abnormal Responses \\
\hline $\begin{array}{l}\text { Before test dose } \\
\text { After test dose }\end{array}$ & $\begin{array}{ll}. . & . \\
\end{array}$ & $\begin{array}{r}19 \\
8 \\
\end{array}$ & $\begin{array}{ll}13 \\
24\end{array}$ & $\begin{array}{l}15 \\
10 \\
\end{array}$ & $\begin{array}{r}9 \\
14\end{array}$ \\
\hline Significance ... & .. $\quad$. & \multicolumn{2}{|c|}{$x^{2}=6.4 ; P<0.05$} & \multicolumn{2}{|c|}{$x^{2}=1 \cdot 3 ;$ N.S. } \\
\hline
\end{tabular}


not. Similar findings were obtained with mean creatinine clearance values above and below $60 \mathrm{ml} / \mathrm{min}$. The six patients whose creatinine clearance had decreased by more than 50 $\mathrm{ml} / \mathrm{min}$ a year before starting treatment with indomethacin (estimated from the duration of proteinuria and the creatinine clearance when first admitted to our hospital; Dotremont et al., 1973) did not show a significantly increased number of modified responses to the platelet aggregation tests after the test dose, whereas the eight patients with a less rapid decline of renal function did.

Inhibition of platelet aggregation after the addition of different concentrations of indomethacin to platelet-rich plasma was also studied. In three patients in whom the proteinuria and urinary excretion of F.R. antigen had responded well to indomethacin administration platelet aggregation was inhibited by indomethacin up to final concentrations of between $3.5 \times$ $10^{-6}$ and $3.5 \times 10^{-7} \mathrm{~mol} / 1$. (healthy controls 1.7-3.5 $\times$ $10^{-6} \mathrm{~mol} / 1$.). In one out of three non-responsive patients platelet aggregation was not inhibited by $3.5 \times 10^{-4} \mathrm{~mol}$ of indomethacin per 1. , and in another $3.5 \times 10^{-5} \mathrm{~mol}$ of indomethacin per 1. had no effect; in the third, however, the in-vitro response of platelet aggregation to indomethacin was normal.

\section{Discussion}

Glomerulonephritis patients on long-term treatment with indomethacin gave normal responses to platelet aggregation tests when the last dose of the drug was taken over 24 hours previously, confirming the observation of O'Brien et al. (1970) that the administration of indomethacin over long periods only slightly prolongs its effect on platelet aggregation and indicating that baseline platelet aggregation in these patients is normal.

A notable observation was that after a test dose of indomethacin the platelet response in the glomerulonephritis group as a whole seemed less striking than in the controls. When the patients with glomerulonephritis were then subdivided according to previous response of proteinuria or urinary excretion of F.R. antigen to indomethacin it became apparent that those patients in whom these indices had responded well had shown significantly more abnormal platelet responses both before and after the test dose than had the group in whom proteinuria and urinary excretion of F.R. antigen had not responded adequately. Thus non-response of proteinuria and urinary excretion of F.R. antigen to indomethacin ingestion in glomerulonephritis patients is associated with a decreased in-vivo inhibition of platelet aggregation by this drug.

This decreased in-vivo inhibition of platelet aggregation by indomethacin in some glomerulonephritis patients may be explained in several ways. While very little is known about the absorption and elimination of this drug in glomerulonephritis reduced plasma levels may be the explanation. The experiments in which indomethacin was added to platelet-rich plasma from the patients, however, suggest that this cannot be the only explanation. That metabolic factors are implicated seems obvious from the finding that poor response is associated with severe proteinuria, lowered creatinine clearance, and previous rapid decline in renal function. Moreover, Bang et al. (1973) showed that platelet aggregation is enhanced in some patients with glomerular renal disease. This enhanced effect was significantly correlated with the degree of proteinuria, and they suggested that plasma proteins inhibiting platelet aggregation may be lost in the urine.

The fact that indomethacin reduces urinary excretion of F.R. antigen and strongly inhibits platelet aggregation in vivo supports but does not prove our hypothesis that the reduction of urinary excretion of F.R. antigen is related, at least in part, to inhibition of intrarenal platelet aggregation and of the subsequent fibrin deposition.

This work was supported by grant Nos. 1216 and 20165 of the Belgian Fonds voor Wetenschappelijk Geneeskundig Onderzoek. Our thanks are due to Miss Annie Vandenbussche for her skilful technical help.

\section{References}

Bang, N. U., Trygstad, C. W., Schroeder, J. E., Heidenreich, R. O., and Csisko, B. M. (1973). Journal of Laboratory and Clinical Medicine, 81, 651 .

Clarkson, A. R., MacDonald, M. K., Cash, J. D., and Robson, J. S. (1972). British Medical fournal, 3, 255.

de Gaetano, G., Donati, M. B., and Vermylen, J. (1971). International fournal of Clinical Pharmacology, Therapy and Toxicology, 5, 196.

de Gaetano, G., Vandenbussche, A., and Vermylen, J. (1972). Experientia, $28,1127$.

Donati, M. B., de Gaetano, G., and Vermylen, J. (1973). Thrombosis Research, 2, 97 .

Dotremont, G., Vermylen, J., Donati, M. B., Van Damme, B., and Michielsen, P. (1973). In Glomerulonephritis, part II, ed. P. Kincaid-Smith, T. H. Mathew, and E. L. Becker, p. 829. Chichester, Wiley.

Forbes, C. D., and Prentice, C. R. M. (1972). In Proceedings of III Congress, International Society on Thrombosis and Haemostasis, p. 190. Washington. American Heart Association.

Forbes, C. D., and Prentice, C. R. M. (1973). Nature New Biology, 241, 109. Michielsen, P., and Verberckmoes, R. (1967). In Abstracts of 3rd International Congress of Nephrology, ed. G. E. Schreiner, p. 243. Basle, Karger.

Michielsen, P., Verberckmoes, R., Desmet, V., and Hemerijckx, W. (1969). fournal d'Urologie et de Néphrologie, 75, 315 .

Michielsen, P., Verberckmoes, R., and Hemerijckx, W. (1970). In Proceedings of IV International Congress of Nephrology, ed. R. Alwall, F. Bergland, and B. Josephson, vol. 3, p. 92. Basle, Karger.

O'Brien, J. R., Finch, W., and Clark, E. (1970). Journal of Clinical Pathology, 23,522 .

Vassalli, P.; and McCluskey, R. T. (1965). American fournal of Medicine, 39, 179.

Vermylen, J., Dotremont, G., Donati, M. B., de Gaetano, G., and Michielsen, P. (1970). European fournal of Clinical and Biological Research, 15, 979.

Vermylen, J., Dotremont, G., Donati, M. B., de Gaetano, G., and Michielsen, P. (1971). Scandinavian fournal of Haematology, Suppl. No. 13, p. 365 . 